\title{
Mental health, well-being, and poverty: A study in urban and rural communities in Northeastern Brazil
}

\section{Bárbara Barbosa Nepomuceno, Antonio Alan Vieira Cardoso, Verônica Morais Ximenes, João Paulo Pereira Barros \& Jáder Ferreira Leite}

To cite this article: Bárbara Barbosa Nepomuceno, Antonio Alan Vieira Cardoso, Verônica Morais Ximenes, João Paulo Pereira Barros \& Jáder Ferreira Leite (2016) Mental health, wellbeing, and poverty: A study in urban and rural communities in Northeastern Brazil, Journal of Prevention \& Intervention in the Community, 44:1, 63-75

To link to this article: http://dx.doi.org/10.1080/10852352.2016.1102590

曲 Published online: 23 Dec 2015.

Submit your article to this journal $₫$

山 Article views: 7

Q View related articles $\sqsubset$

View Crossmark data ¿ 


\title{
Mental health, well-being, and poverty: A study in urban and rural communities in Northeastern Brazil
}

\author{
Bárbara Barbosa Nepomuceno ${ }^{a}$ Antonio Alan Vieira Cardoso ${ }^{a}$, Verônica Morais \\ Ximenes ${ }^{\mathrm{a}}$, João Paulo Pereira Barros ${ }^{\mathrm{a}}$, and Jáder Ferreira Leite ${ }^{\mathrm{b}}$ \\ aDepartment of Psychology, Federal University of Ceará, Fortaleza, Ceará, Brazil; 'Department of \\ Psychology, Federal University of Rio Grande do Norte (UFRN), Natal, Rio Grande do Norte, Brazil
}

\begin{abstract}
This article analyzes the relations between mental health and well-being in urban and rural contexts marked by poverty. The analysis takes as its basis a quantitative research conducted with 417 adult inhabitants of two communities, one rural and the other urban, in Northeastern Brazil. The data were constructed using questionnaires composed of sociodemographic data, the Personal Wellbeing Index and Self Report Questionnaire (SRQ-20) scales. We found significant differences between the inhabitants of the rural and urban communities regarding well-being and the prevalence of common mental disorders (CMD), with a higher average well-being score in the rural context; the urban sample had a higher average regarding the prevalence of CMD. The variable income significantly influenced the SRQ-20 average scores; the same was not observed with well-being scores. Besides, it was observed that there is a negative correlation with well-being and CMD.
\end{abstract}

\section{KEYWORDS}

Mental health; poverty; psychology; well-being

\section{Introduction}

This article analyzes the relationship between mental health and well-being in rural and urban Brazilian contexts marked by poverty. This study is one of the outcomes of a survey on psychosocial implications of poverty, conducted with 417 subjects that live in an urban community located in the neighborhood of Bom Jardim in Fortaleza, Brazil and a rural community located in the Canafístula district, in the city of Apuiarés, Brazil.

Poverty is a multidimensional phenomenon forged and perpetuated amid the neoliberal capitalist system, starting in structural processes of exclusion and social inequality (Accorssi, 2011; Demo, 2001), with striking implications for the well-being and health status of the population. A variety of concepts of poverty divided in one-dimensional and multidimensional perspectives (Accorssi, 2011), can be identified. The first analyzes the phenomenon in terms of a single factor, nutritional needs or income, for example. The latter considers that poverty manifests itself in a complex manner, through multiple 
dimensions and in it, there is not a single factor able to decide who lives or not in poverty conditions.

From the multidimensional perspectives, which have Sen (2010) as its main exponent, it is possible to expand the spectrum of comprehensions of poverty beyond income deprivation, moving to an understanding of the various impacts it has on the lives of individuals, on the development of individual potential and on the establishment of a dignified life. In this sense, Bastos, Rabinovich, and Almeida (2010) argue that poverty implies a kind of existence, a way of being in the world, woven from macro- and microsocial relations. Cidade, Moura Jr., and Ximenes (2012) argue that poverty, beyond material deprivation, has psychosocial effects in the subject's way of life, the expression of the possible existence, resistance and the overcoming of adversity, from the structural, symbolic, social, and economic preconditions.

Brazil is one of the most unequal countries in the world, where 16.2 million people live in extreme poverty, with $59 \%$ of those living in the Northeast region (IBGE, 2011). Out of the total of Brazilian residents living in the countryside, one in four suffer from extreme poverty $(25.5 \%)$, which characterizes rural environment as one of the most precarious in Brazil. In this region reside $47 \%$ of the poor people in Brazil (IBGE, 2011). Leal (2011) states that a quarter of the extremely poor in Brazil live in a rural area, with 5.7 million of these people having a per capita income of $\mathrm{R} \$ 1$ to 70 reais ${ }^{1}$ per month and 1.8 million lacking an income of their own. This reality contributes to rural flight, which intensifies the uncontrolled growth of large cities. From 1990 to 2010, two million people have migrated from rural to urban areas (IBGE, 2011).

The countryside was traditionally portrayed as a privileged locus of labor relations, considered neither modern nor capitalist, mostly marked by subsistence farming. Currently, studies on rural contexts show the existence of a "new rural area" in which typical urban occupations, such as those of the service sector, are combined with the traditional characteristics of rural activities. Those studies also highlight the existence of a diversity of local realities in rural areas (Carneiro, 2012).

Leite, Macedo, Dimenstein, and Dantas (2013) point out other features present in some Brazilian rural contexts, such as: the dependence on programs and actions of the federal government in light of the economic and administrative fragilities; the strong presence of centralizing municipal administrations; the existence of problems such as infant mortality, illiteracy, child labor, poverty, unemployment, hunger, malnutrition, precarious public transportation or lack thereof, in addition to the presence of typical problems of urban centers, such as violence, crime, drug consumption and trafficking, and chronic-degenerative diseases.

Accordingly, in order to contextualize Brazilian cities, it is suitable start from the notes of Baptista (1997) and Josephson (1997), and highlight some characteristics of urban settings configured in recent years that have 
considerable impact on poverty conditions in these places: faster displacement that configures their public spaces as one of passage, not encounter; new regimes of inequality due to the deepening of urban segregation processes; and the adoption of selective and isolation practices of the poor as a way of ordering urban spaces.

Comparing rural and urban contexts, Góis (2005) and Ximenes and Moura Jr. (2013), consider that in rural contexts it is possible to witness a greater affective connection between residents and their families, a fact that is observed to a lesser extent in the urban contexts, among other aspects, due to the great mobility in the city, the fear of violence, and a great appreciation of individuality.

Regarding the relationship between health and personal well-being, it is important to emphasize that the understanding of mental health has historically gone through transformations. Currently, it is considered that mental health is a complex and multidetermined phenomenon influenced by biological, psychological, social, cultural, economic, and moral influences (Alves \& Rodrigues, 2010; Organização Mundial de Saúde [OMS], 2002). It is acknowledged that in the construction of mental health and psychological distress process the context in which the subject lives and their unique life stories are influential. The same disease, from the point of view of classification, is experienced by each subject in different ways, depending on the subjective and material resources that each person has and is expressed as a way of positioning of the subject regarding the conflicts and contradictions that they face.

In this sense, Nepomuceno (2013) highlights that a process of psychological distress woven in poverty will have specific patterns closely linked to the person who experiences it, being that the specificities present in this as psychosocial scenario are experiences of shame and humiliation, fatalism, blaming the poor, physical and symbolic violence, continued stress and poor access to mental health care. According to the World Health Organization OMS (2002), the poor and the disadvantaged have a higher prevalence of mental and behavioral disorders.

To Patel and Kleinman (2003) common mental disorders (CMD) should be placed on the list of diseases associated with poverty. In this association lie factors like experience of insecurity and hopelessness, rapid social change and risks of physical violence. According to them, the direct and indirect costs of psychological distress can worsen the economic situation, establishing a circular relationship between poverty and CMD. In the same direction, other studies also suggest such associations between poverty and CMD (Lopes, Faerstein, \& Chor, 2003; Ludemir, 2008; Ludemir \& Melo Filho, 2002).

CMD are characterized by non-psychotic distress and lack of organic pathology associated, expressed through "symptoms such as insomnia, fatigue, irritability, forgetfulness, difficulty concentrating, and somatic complaints" (Ludemir \& Melo Filho, 2002, p. 214). Its prevalence tends to be higher among 
women and is strongly related to social, psychosocial and economic vulnerability environments.

According to Minayo (2000), the discussions around health and quality of life are present in the field of public health since the birth of social medicine. According to the author, "in all surveys made on quality of life, non-material values such as love, freedom, solidarity and social integration, personal fulfillment and happiness comprise its conception" (Minayo, 2000 p. 4). This reveals that in the study of the relationship between quality of life and health, not only socioeconomic but also cultural and subjective aspects are present, and they are a part of the personal well-being concept, which refers to "feeling globally well along the life cycle" (Sarriera et al., 2012, p. 92).

Personal (or subjective) well-being has been investigated in several studies seeking to understand which variables "cause individuals to evaluate their life as generally satisfactory" (Sarriera et al., 2012, p. 92). This, according to Diener, Oishi, and Lucas (2003, as cited in Pais-Ribeiro \& Cummins, 2008, p. 1), is the "emotional and cognitive evaluation that people make about their lives, and includes what ordinary people refer to as happiness, peace, fulfillment, and satisfaction with life." For Guedea and colleagues (2006), personal well-being is an important indicator of mental health, since it is important for the evaluation that the subject makes of herself and her life.

For Albuquerque and Tróccoli (2004) the concept of subjective well-being has three fundamental dimensions: positive and negative affects and life satisfaction. Positive and negative affect are related to a description of an emotional state, given that life satisfaction involves a cognitive judgment in any area of the subject's life (Albuquerque \& Tróccoli, 2004). According to Casas and Bello (2012, p. 29), "it is, fundamentally, to feel well, enjoy, be satisfied. Therefore, the individual and collective functioning of constructs like happiness, life satisfaction and satisfaction, with distinct spheres of life are among its main investigation goals."

In this sense, socioeconomic, cultural, and subjective conditions are critical in assessing what subjects make of themselves and their lives, interfering with their well-being and consequently with their mental health. Lever, Piñol, and Uralde (2004) show an association between low levels of well-being and shortages of life in poverty. Therefore it is worth investigating how the phenomena of poverty, mental health, and personal well-being are related, considering also the expression of these factors in rural and urban contexts.

\section{Method}

This research has a quantitative character and was conducted in two communities in the state of Ceará, in Northeastern Brazil: the Bom Jardim community, located in the city of Fortaleza and the Canafístula community, located in the rural municipality of Apuiarés. 
The neighborhood of Bom Jardim, representing the urban context, lies in the southwest of the state capital and has an estimated population of 220,000 inhabitants. It is characterized by being the most populated and poor region of the capital (IPECE, 2012). Most parts of the population face problems such as homelessness, unemployment, lack of safety, poor education, lack of transportation, and health, insecurity, and poor neighborhood infrastructure. The Canafístula neighborhood is a rural community located about $26 \mathrm{~km}$ away from the town of Apuiarés and $118 \mathrm{~km}$ from Fortaleza. In the community live around 170 families (about 1,000 people) and their source of income comes mainly from family farming, social benefits, public employment, and pensions.

In total 417 adults participated in the survey, both sexes, with 177 men $(28.1 \%)$ and 299 women $(71.9 \%){ }^{2}$ aged between 18 and 88 years (average age: 40, SD: 17.33), with 208 from Canafístula and 209 from Bom Jardim. Regarding the income, $25.2 \%$ of people earn less than 85 reais monthly income, $54.7 \%$ earn more than 85 and less than 678 reais and $20.1 \%$ of people earn more than 678 reais.

The research data were constructed from questionnaires, conducted by researchers and collaborators, constructed from sociodemographic data (age, gender, type of community, income, religion, education, etc.) and scales such as the Personal Wellbeing Index (PWI) and Self Report Questionnaire (SRQ-20), who analyze subjective well-being and CMD, respectively.

The PWI (Cummins, Eckersley, Pallant, Van Vugt, \& Misajon, 2003) is a questionnaire that aims to assess subjective well-being, focusing mainly on the personal satisfaction dimension. The instrument assesses subjects' satisfaction regarding quality of life domains such as: standard of living, health, achievement in life, relationships, safety, community connection, future, security, and spirituality/religion (International Wellbeing Group [IWG], 2006). The SRQ-20, developed by the World Health Organization (WHO), is widely used in mental and health research and is "intended to detect symptoms, which means it suggests a level of suspicion (presence/ absence) of any mental disorder" (Santos, Araújo, Pinho, \& Silva, 2010). The SRQ-20 is not intended to outline a specific diagnosis, instead assisting in tracking non-psychotic mental disorders. Its validation in Brazil was performed by Mari and Williams (1986). The data compiled were tabulated and analyzed using the software Statistical Package for Social Sciences (SPSS) 20.0.

The research obliged to the parameters and items of the Resolution No. 196 of 1996 of the Brazilian National Health Council, which regulates research involving human beings, being submitted to the Federal University of Ceará Research Ethics Committee and approved with CAAE: 07810512.3.0000.5054. 


\section{Results}

The overall average of personal well-being of the sample of 417 subjects was $7.96(S D=1.51)$. As can be seen in Table 1 , the item that had the highest average was satisfaction in relation to spirituality or religious beliefs $(M=8.84, S D$ $=1.84)$. The lowest mean $(M=6.75, S D=3.07)$ was observed in "Satisfaction with the feeling of being safe."

Taking into consideration the rural and urban samples, it was found that the average score of well-being in the rural community $(M=8.28, S D=1.27)$ was higher than in the urban community $(M=7.64, S D=1.67)$. This difference was statistically significant $(t(386)=-4.203, p<.001)$.

Changes in income of individuals, be that the family $(r=.66, p>001)$ or individual income $(r=.15, p>.001)$ did not imply a significantly different average well-being score. Moreover, whether or not someone in the family is getting income from a governmental benefit program is not related to significant differences of average well-being scores $(t(382)=-1.834$, $p>.001)$.

Aiming at identifying possible predictive variables for the well-being levels in the sample, we performed a Simple Linear Regression analysis, which showed that the total index of the SRQ-20 has the power to explain part of the variance of well-being average scores. Regarding the general index of the scale, we discovered that the value of $\mathrm{R}$ square $\left(R^{2}=.140\right)$, indicates that the index of the SRQ-20 was able to explain $14 \%$ of the total variance of the well-being average in the sample (Table 2). This model has a significantly good degree of prediction of the values of the well-being variable $(F=57.63, p<.001)$ (Table 3$)$. The correlation between well-being and total SQR-20 scale can be observed by means of the correlation coefficient $(r=-.37, p<.001)$, which also indicates that the correlation is negative.

Considering the results from the SRQ-20, it was observed that subjects of the urban community had a higher mean $(M=.35, S D=.25)$ than participants from rural areas $(M=.28, S D=.20)$. This difference was statistically significant $(t(361.17)=3.11, p<.05)$. Proving the negative correlation between well-being and CMD, the urban sample had a lower well-being average and a higher average propensity to psychological distress, when compared to the rural population.

Taking into account the relationship between income and SRQ-20, it is possible to see, through the one-way analysis of variance (ANOVA) test, that there is a significant effect of personal income on the average score of the SRQ-20 $(F(4.364)=4.34, p<.05)$. It can be observed in Table 4 that the straits of the population analyzed with lower income have higher averages in the SRQ-20, which gives us evidence of a higher prevalence of CMDs among these subjects. 
Table 1. Descriptions of statistics about the items of personal well-being.

\begin{tabular}{lccc}
\hline Items & N & Mean & Standard Deviation \\
\hline Satisfaction with one's health & 409 & 7.56 & 2.65 \\
Satisfaction with your level of life & 407 & 7.80 & 2.20 \\
Satisfaction with you have obtained during your life & 408 & 8.22 & 2.16 \\
Satisfaction with the sensation to be secure & 410 & 6.75 & 3.07 \\
Satisfaction with the groups of people you are part of & 410 & 8.36 & 2.13 \\
Satisfaction with security about the future & 410 & 7.53 & 2.46 \\
Satisfaction with the relations with other people & 412 & 8.38 & 1.99 \\
Satisfaction with your spirituality or religious beliefs & 412 & 8.84 & 1.84 \\
Valid N (listwise) & 388 & & \\
\hline
\end{tabular}

Table 2. Summary of the model of the regression analysis.

\begin{tabular}{lcccc}
\hline Model & $\mathrm{R}$ & $\mathrm{R}$ Square & Adjusted R Square & Std. Estimate Error \\
\hline 1 & $.375^{a}$ & .140 & .138 & 1.37 \\
\hline a.Previsores: (Constant), Total_SRQ20. & & &
\end{tabular}

Table 3. Significance level of the regression analysis.

\begin{tabular}{llccccc}
\hline Modelo & & Sum of Squares & df & Mean Square & $F$ & Sig. \\
\hline 1 & Regression & 109.107 & 1 & 109.107 & 57.63 & $.000^{b}$ \\
& Residual & 668.279 & 353 & 1.893 & & \\
\hline & Total & 777.386 & 354 & & & \\
\hline
\end{tabular}

a.Dependent Variable: Well Being Personal Index.

b. Previsores: (Constante), Total_SRQ20.

Table 4. Means of SRQ-20 from different levels of income.

\begin{tabular}{lccc}
\hline Personal Income & N & Mean SQR-20 & Standard Deviation \\
\hline Under $R \$ 85,00$ & 90 & .3733 & .2549 \\
$\mathrm{R} \$ 85,00$ to $R \$ 170,00$ & 36 & .3444 & .2147 \\
$\mathrm{R} \$ 170,00$ to $\mathrm{R} \$ 339,00$ & 58 & .3828 & .2436 \\
$\mathrm{R} \$ 339,00$ to $\mathrm{R} \$ 678,00$ & 106 & .2783 & .2268 \\
$\mathrm{R} \$ 678,00$ or more & 79 & .2646 & .2075 \\
\hline
\end{tabular}

\section{Discussion}

Analyzing the indices of personal well-being and SRQ-20 scores, there are significant differences between the types of community (rural or urban), with the best overall average rates of mental health and well-being among residents of rural areas. According to Alves and Rodrigues (2010), there is an association between living in big cities and risk of psychological distress. For them, this is due to the presence of factors such as stress and coping with everyday adverse circumstances, weakened social support, difficulty in accessing essential goods and less healthy lifestyles, present in the urban centers.

Such factors are also reported by Albuquerque, Martins, and Neves (2008), in a study on well-being in rural and urban contexts. They point out that despite the rural context, in recent decades, no longer being exclusively 
agrarian it is still associated with being a pleasant and healthy place to live, where interpersonal relationships are closer and lasting, thus favoring a greater emotional stability and an improvement of personal well-being. The urban environment, however, is commonly marked by unstable relationships that generate, on many subjects, more volatile bonds, which, associated with higher rates of violence and stress, for instance, help making life in this context, especially for those living in the peripheries marked by misery, to be evaluated by its residents as less satisfactory than in the rural environment. The family and community relationships more present in the rural context (Góis, 2005; Ximenes \& Moura Jr., 2013) are important to cope with adverse situations peculiar to the poverty context and, when strengthened, usually favor wellbeing and mental health (Prezza \& Costantini, 1998).

Lever, Piñol, and Uralde (2004) point out that studies linking well-being and income have two main types: one considers that there is a strong relationship between financial status and well-being (when the population impoverishes their well-being decreases); for the other, the relationship between subjective well-being and material situation is very limited. More than the economic situation, psychological and social situations explain more satisfactorily the variance in well-being.

This second conception seems to fit better to the data provided by the statistical analyses of the scale of personal well-being, to the extent that income did not influence significantly the subjects examined. This result confirms that financial deprivation is not necessarily the determinant factor of a low level of life satisfaction. As pointed out by Diener and Lucas (2000, as cited in Casas \& Bello, 2012), analyses of the influence of external factors on the subjective wellbeing show that income (above subsistence levels), body image, and health have very modest effects on long-term well-being. For the authors, sociodemographic variables have little power to explain the variance of the construct. Because of this, researchers have adopted research models of subjective well-being that evaluate the influence of other psychological variables, such as personality factors (introversion/extroversion), goal achievement, culture, among others (Casas \& Bello, 2012).

Nevertheless, the relationship between income and mental health is expressed otherwise. Confirming the studies of Lopes, Faerstein, and Chor (2003) and Ludemir and Melo Filho (2002), who state the development of CMD among people with lower income is significantly greater. For the authors, lack of money may lead to stress and insecurity, which cause CMD. Importantly, among subjects with low income, low education, unemployment, and labor unrest are usually associated, all of these provoking continued stress (Góis, 2008) that weakens personal and social development.

Ludemir (2008) highlights the existence of a positive association between social class inequality and CMD and that the variable income is one of the most studied and consistent in the national and international literature as 
associated with non-psychotic mental disorders. According to the author, "social inequalities involve the main feelings related to depression and other mental disorders, such as humiliation, inferiority, perceived lack of control over the environment and impotence" (Ludemir, 2008, p. 461). The high rates found in the SRQ-20, among the population in poverty and extreme poverty, confirm such statements.

According to Lever, Piñol, and Uralde (2004), in the analysis of well-being, and Patel and Kleinman (2003), in the analysis of the CMD, the phenomenon of poverty is a state of life that involves patterns and psychosocial strategies that differentially influence the subjective well-being and mental health of individuals, working as mediating factors. Some of the psychosocial variables that are involved in mediating this relationship are: strategies for coping with stress, locus of control, motivation to perform daily activities, self-esteem, and depression. Thus, the possibility is opened to work toward modification of these psychosocial patterns, which may increase people's well-being and mental health. More than that, it creates conditions for people in poverty to perceive themselves as able to fight for the transformation of their lives.

On the other hand, we found a high level of well-being among the subjects, even among subjects living amid hardship; their levels remained constant relative to the overall mean. According to Casas and Bello (2012), in population studies on well-being, most people tend to respond above the neutral point on any scale with opposite ends, regardless of their sociodemographic characteristics. There is, for the authors, a trend or bias for vital optimism in the functioning of subjective well-being for all cultures. From this they observed that, when it was shown that this bias tends to be stable within each culture, the existence of a cultural homeostasis of subjective well-being or happiness is proposed.

A relationship between high levels of satisfaction and life in poverty may be established with the psychosocial phenomenon of fatalism. According to Martin Baró (1987), this phenomenon is related to a resignation of the subject regarding his own destiny; acceptance of suffering; submission, passiveness, and conformism; ideas marked by predefinition of life and religion. This phenomenon, besides being an aspect that contributes to the persistence of individuals in poverty, can also be regarded as a form of oppressing survival that the poor individual has in order to deal with an adverse reality. For Cidade, Moura Jr., and Ximenes (2012, p. 94), "it is observed that the annulment of suffering, anguish and despair of poor people in understanding their reality as oppressive and marginalizing is founded in an adaptive response to this Latin American reality."

For the authors, therefore, in the face of feelings of insecurity and lack of perspective on life, the Latin American people establish an attitude of resignation with the adversities of life justified through a fatalistic explanation of 
these adversities. In this sense, this is understood as a positive evaluation of life, even in contexts marked by social inequality and oppression.

Regarding the relationship between mental health and well-being, according to the statistical analyses, individuals who are more prone to psychological distress tend to have lower well-being means, thereby establishing a negative correlation between these phenomena. The predictive power of the CMD variable over the variance of well-being is small, indicating that there are many other variables that influence it. Thus, it is important to further the analyses so that more robust models of explanation of personal well-being may be established. Moreover, it is necessary to investigate how the construct multidimensional poverty may or may not influence on well-being scores.

\section{Final considerations}

It is concluded from the data obtained that there exists an increased presence of poverty in rural areas; on the other hand, levels of well-being and mental health are better in this context. This finding demonstrates that despite economic and structural difficulties of the rural population, there are psychosocial protective and empowering elements that enable an improved quality of life. This shows that the style of organization and life of the great cities weakens its residents and leave them more vulnerable to developing psychological distress. It is important that future studies discuss and deepen the psychosocial elements involved in this process.

It is also clear that dealing with issues such as poverty and psychological distress; social, cultural, economic, and natural order should be considered. As well as the particularities of the contexts in which such phenomena are structured and maintained.

\section{Notes}

1. 1 (one) American dollar equals approximately 2.35 (two point thirty five) reais (Brazilian currency).

2. One missing case.

\section{Funding}

This research was funded by the Human and Social Sciences Announcement 07/2011 from the National Council for Scientific and Technological Development (CNPq) and by the Research Productivity Fellowship of CNPq from Verônica Morais Ximenes.

\section{References}

Accorssi, A. (2011). Materializações do pensamento social sobre a pobreza. [Materializations of social though on poverty] Thesis (Doutorado em Psicologia), Pontifícia Universidade Católica do Rio Grande do Sul, Porto Alegre, Brazil. 
Albuquerque, A. S., \& Tróccoli, B. T. (2004). Desenvolvimento de uma escala de bem-estar subjetivo. [Development of a subjective well-being scale]. Psicologia: Teoria e Pesquisa, 20 (2), 153-164. doi:10.1590/s0102-37722004000200008

Albuquerque, F. J. B., Martins, C. R., \& Neves, M. T. S. (2008). Bem-estar subjetivo emocional e coping em adultos de baixa renda de ambientes urbano e rural. [Subjective well-being and coping in adults with low income in urban and rural environments]. Estudos de Psicologia (Campinas), 25(4), 509-516. doi:10.1590/s0103-166×2008000400005

Alves, A. A. M., \& Rodrigues, N. F. R. (2010). Determinantes sociais e econômicos da Saúde Mental. [Social and economic determinants of mental health]. Revista Portuguesa de Saúde Pública, 28(2), 127-131. doi:10.1016/s0870-9025(10)70003-1

Baptista, L. A. S. (1997). As cidades da falta. In A. E. Silva (Ed.), Saúde-loucura, número 6 (Subjetividade) [Health-madness, number 6 (Subjectivity)] (pp. 170-182). São Paulo, Brazil: HUCITEC.

Bastos, A. C. S., Rabinovich, E. P., \& Almeida, M. B. (2010). Living the world of poverty: The researcher as participant/apprentice. Psychology \& Developing Societies, 22(2), 221-247. doi:10.1177/097133361002200202

Carneiro, M. J. (2012). Ruralidades Contemporâneas: Modos de viver e pensar o rural na sociedade brasileira. [Contemporary ruralities: Ways of living and thinking the rural in Brazilian society]. Rio de Janeiro, Brazil: Mauad/FAPERJ.

Casas, F., \& Bello, A. (2012). Calidad de vida y bienestar infantil subjetivo en España ¿Qué afecta al bienestar de niños y niñas españoles de $1^{\circ}$ de ESO? [Quality of life and child well-being in Spain: What does affect the well-being of Spanish boys and girls of the $1^{\circ}$ ESO?]. Madrid, Spain: Unicef España.

Cidade, E. C., Moura, J. F., Jr., \& Ximenes, V. M. (2012). Implicações psicológicas da pobreza na vida do povo latino-americano. [Psychological implications of poverty in the life of Latin-American people]. Psicologia Argumento, 30(68), 87-98. doi:10.7213/psicol. argum. 5886

Cummins, R. A., Eckersley, R., Pallant, J., Van Vugt, J., \& Misajon, R. (2003). Developing a national index of subjective wellbeing: The Australian unity wellbeing index. Social Indicators Research, 64, 159-190.

Demo, P. (2001). Pobreza política. [Political poverty]. Campinas, Brazil: Autores Associados.

Diener, E., Oishi, S. \& Lucas, R. (2003). Personality, culture, and subjective well-being: emotional and cognitive evaluations of Life. Annual Review of Psychology, 54, 403-425.

Góis, C. W. L. (2005). Psicologia comunitária: Atividade e consciência. [Community psychology: Activity and conscience]. Fortaleza, Brazil: Publicações Instituto Paulo Freire.

Góis, C. W. L. (2008). Saúde Comunitária: Pensar e fazer. [Community health: Thinking and doing]. São Paulo, Brazil: Editora HUCITEC.

Guedea, M. T. D., Albuquerque, F. J. B., Tróccoli, B. T., Noriega, J. A. V., Seabra, M. A. B., \& Guedea, R. L. D. (2006). Relação do bem-estar subjetivo, estratégias de enfrentamento e apoio social em idosos [Relationship of subjective well-being, coping strategies and social support in the elderly]. Psicologia: Reflexão e Crítica, 19(2), 301-308.

IBGE. (2011). Indicadores sociais municipais: Uma análise dos resultados do universo do censo demográfico 2010. [Municipal social indicators: An analysis of the results from the universe of the 2010 demographic census] Estudos e Pesquisas Informação Demográfica e Socioeconômica (número 28). Rio de Janeiro, Brazil: IBGE. Retrieved from http://biblioteca.ibge.gov. br/visualizacao/livros/liv54598.pdf

International Wellbeing Group (IWG). (2006). Personal wellbeing index. Melbourne, Australia: Australian Centre on Quality of Life, Deakin University. Retrieved from http://www. deakin.edu.au/research/acqol/instruments/wellbeing_index.htm 
IPECE. (2012). Perfil Municipal de Fortaleza. [Municipal profile of Fortaleza]. Tema VIII: O Mapa da Extrema Pobreza. Informe $n^{\circ}$ 43. Fortaleza, 2012. Retrieved from http://www. ipece.ce.gov.br/publicacoes/ipece-informe/Ipece_Informe_43_05_novembro_2012.pdf

Josephson, S. C. (1997). Espaços urbanos e estratégias de hierarquização. [Urban spaces and strategies of hierarchization]. In A. E. Silva (Ed.), Saúde-Loucura, número 6 (Subjetividade) (pp. 143-154). São Paulo, Brazil: HUCITEC.

Leal, L. N. (2011). Área rural receberá atenção especial do Brasil sem Miséria. [Rural area will receive special attention from Brasil sem Miséria]. Estadão. Retrieved from http://www.estadao.com.br/ noticias/nacional,área-rural-recebera-atencao-especial-do-brasil-sem-miseria,770604,o.htm.

Leite, J. F., Macedo, J. P. S., Dimenstein, M., \& Dantas, C. (2013). A formação em psicologia para a atuação em contextos rurais. [Formation in psychology for acting in rural contexts]. In J. F. Leite \& M. Dimenstein (Eds.),. Psicologia e contextos rurais [Psychology and rural contexts] (pp. 27-55). Natal, Rio Grande do Norte, Brazil: EDUFRN.

Lever, J. P., Piñol, N. L., \& Uralde, J. H. (2004). Pobreza, recursos psicológicos y bienestar subjetivo. [Poverty, psychological resources and subjective well-being]. Mexico City, México, DF: Universidad Iberoamericana.

Lopes, C. S., Faerstein, E., \& Chor, D. (2003). Eventos de vida produtores de estresse e transtornos mentais comuns: Resultados do Estudo Pró-Saúde. [Stress-producing life events and common mental disorders: Results from the Pró-Saúde study]. Cadernos de Saúde Pública, 19(6), 1713-1720. doi:10.1590/s0102-311x2003000600015

Ludemir, A. B. (2008). Desigualdade de classe, gênero e saúde mental nas cidades. [Class inequality, gender and mental health in cities]. Physis: Revista de Saúde Coletiva, 18(3), 451-467. doi:10.1590/s0103-73312008000300005

Ludemir, A. B., \& Melo Filho, D. A. (2002). Saúde mental, condições de vida e estrutura ocupacional. [Mental health, life conditions and occupational structure]. Revista de Saúde Pública, 36(2), 213-231. doi:10.1590/s0034-89102002000200014

Mari, J. J., \& Williams, P. (1986). A validity study of a psychiatric screening questionnaire (SRQ-20) in primary care in the city of São Paulo. The British Journal of Psychiatry, 148, 23-26. doi:10.1192/bjp.148.1.23

Martín-Baró, I. (1987). El latino indolente. Carácter ideológico del fatalismo latinoamericano. In M. Montero (Ed.), Psicología política latinoamericana (pp. 135-162). Distrito Capital, Caracas, Venezuela: Panapo.

Minayo, M. C. (2000). Qualidade de vida e saúde: Um debate necessário. [Quality of life and health: A necessary debate]. Ciência \& Saúde Coletiva, 5(1), 7-18. doi:10.1590/s141381232000000100002

Nepomuceno, B. B. (2013). Pobreza e saúde mental: Uma análise psicossocial a partir da perspectiva dos usuários do centro de atenção psicossocial (CAPS). [Poverty and mental health: A psychosocial analysis from the perspective of users of the center for psychosocial attention (CAPS)] Dissertação (Mestrado em Psicologia). Universidade Federal do Ceará. 151f. Fortaleza, Brazil.

Organização Mundial de Saúde (OMS). (2002). Saúde mental: Nova concepção, nova esperança. [Mental health: New conception, new hope]. Lisboa, Portugal: Relatório mundial da saúde.

Pais-Ribeiro, J., \& Cummins, R. (2008). O bem-estar pessoal: Estudo de validação da versão portuguesa da escala. [Subjective well-being: Validation study of the portuguese version of the scale]. In I. Leal, J. Pais-Ribeiro, I. Silva, \& S. Marques (Eds.), Actas do $7^{\circ}$ congresso nacional de psicologia da saúde (pp. 505-508). Lisboa, Portugal: ISPA.

Patel, V., \& Kleinman, A. (2003). Poverty and common mental disorders in developing countries. Bulletin of the World Health Organization, 8(8), 609-615. Retrieved from http://www. who.int/bulletin/volumes/81/8/Patel0803.pdf 
Prezza, M., \& Costantini, S. (1998). Sense of community and life satisfaction: Investigation in three different territorial contexts. Journal of Community \& Applied Social Psychology, 8, 181-194. doi:10.1002/(sici)1099-1298(199805/06)8:3<181::aid-casp436>3.0.co;2-4

Santos, K. O. B., Araújo, T. M., Pinho, P. S., \& Silva, A. C. C. (2010). Avaliação de um instrumento de mensuração de morbidade psíquica: Estudo de validação do self-reporting questionnaire (SRQ-20). [Evaluation of an instrument for measuring psychic morbidity: Validation study of the self-reporting questionnaire (SRQ-20)]. Revista Baiana Saúde Publica, 34(3), 544-560.

Sarriera, J. C., Ximenes, V. M., Bedin, L. M., Rodrigues, A. L., Schütz, F. F., Montserrat, C., \& Silva, C. L. (2012). Bem-estar pessoal de pais e filhos e seus valores aspirados. [Personal well-being of parents and children and their desired values]. Aletheia Canoas, 37, 91-104.

Sen, A. (2010). Desenvolvimento como liberdade. [Development as freedom]. São Paulo, Brazil: Companhia das Letras.

Ximenes, V. M., \& Moura, J. F., Jr. (2013). Psicologia comunitária e comunidades rurais do Ceará: Caminhos, práticas e vivências em extensão universitária. [Community psychology and rural communities of Ceará: Paths, practices and experiences in university extension]. In J. F. Leite \& M. Dimenstein (Eds.), Psicologia e contextos rurais (pp. 453-476). Natal, Rio Grande do Norte, Brazil: EDUFRN. 